\title{
Information Needs of Youths involved in Urban Agriculture as Strategy for Checking Unemployment in Epe Lga of Lagos State, Nigeria
}

\section{${ }^{* 1}$ EDEOGHON CO; DU. OKOEDO-OKOJIE ${ }^{2}$}

\author{
Department of Agricultural Economics and Extension Service,
}

Faculty of Agriculture, University of Benin, Benin City.

KEYWORDS: Information, Needs, Urban Agriculture, Unemployment

\begin{abstract}
This study assessed the information needs of youths involved in urban agriculture in Epe LGA of Lagos state, Nigeria. Data was generated by means of structured questionnaire from 140 respondents and analyzed with frequency counts, percentages, means and chi-square was used for hypothesis testing. Most (50.7\%) were males, majority (71.4\%) were unemployed. Most (54.3\%) need information on crop production, 35.0\% source agriculture information through extension agents, urban agriculture can be a solace for unemployed $(X=4.27)$ was a high perception. Vegetable $(X=3.52)$, maize $(X=3.47)$, cassava $(\mathrm{X}=3.23)$ and fish production $(\mathrm{X}$ 4.12) was their major agricultural tasks. Unemployment was caused by laziness, lack of knowledge and god-fatherism. Respondents' level of education $\left(x^{2}=13.465: p<0.05\right)$ and primary occupation $\left(x^{2}=7.125: p<0.05\right)$ had significant association with their perceived information needs. It was recommended that the department of agriculture in Epe LGA and the Lagos state Agricultural Development Programme (ADP) should provide youths with information needed in agriculture especially crops and fish production where interest have been indicated. (C) JASEM
\end{abstract}

\section{http://dx.doi.org/10.4314/jasem.v19i1.5}

\section{Introduction}

Urban agriculture is an agricultural practice that is carried out within or on the outskirts of a city where a non-agricultural use of local resource is a real option (Moustier, 1998). Urban agriculture can spawn or help sustain a range of new industries and employment opportunities in and near cities, which include compost production and supply, seed, tool and related supply houses, marketing and distribution, including rejuvenated farm markets, farmer consumer cooperatives, exchange trading systems and work itself (Garnett, 1996). Urban agriculture affects the city economy and supports new industries and also offers employment opportunities which include; marketing, supply, distribution, farming tools and compost making (Rees, 1997). Urban agriculture also generates income to urban dwellers that are involved in urban farming where the income earned is spent on non-food items, thus, contributing to poverty alleviation among the urban poor dwellers e.g. health cares, transport, housing, etc. (Jacobi, 1998). Urban agriculture complements rural agriculture to a large extent and increases the efficiency of the national food system in that it provides products that rural agriculture cannot supply easily (e.g. perishable products, products that require rapid delivery upon harvest) that can replace food imports and it can thus release lands for export production of commodities (International Development Research Centre (IDRC), 1998).
Urban youth unemployment according to Onah (2001) stands for the conglomerate of youths with diverse backgrounds, willing and able to work in urban areas. This results in pressures of supply of labour force over the demand for labour, thus causing joblessness. Todaro (1992) points out that the high rate of urban unemployment is as a result of continuous transfer of economic activities and youths from rural to urban population movement, stagnating agricultural productivities and growing urban youth unemployment. This is as a result of unbalanced development. The large-scale unemployment among youth is encouraging the development of street youths in Nigeria. The street youth, denied of legitimate means of livelihood, grow up in a culture that encourages criminal behaviour (Chigunta, 2002).

Bennel (2000) argued that urban society is becoming increasingly criminalized, especially with the proliferation of youth gangs. Several studies have shown that majority of prison inmates are youth aged 30 years and below. Also, delinquency, crime and drug abuse are on the increase among youth (Igbinovia, 1998). According to Heckman et al (1987) Labour Force Surveys have shown that the rate of unemployment is significantly higher in urban areas than rural areas. This is because rural areas usually have more self-employed workers whether in family farms or non-agricultural enterprises. Youth in any society have the potentials to stimulate economic growth, social progress and overall national development. For the purpose of this study, a youth is 
regarded as an individual that is between $15-50$ years of age including both male and female in general.

An assessment of the year 2005 (Smit, 1996) suggested that, worldwide urban food production will continue to expand between 1993 and 2005, urban agriculture has increased its share of world food production from $15 \%$ to 25 to $33 \%$, its share of vegetables, meat, fish and diary products consumed in cities from 200 million to 400 million (Smit, 1996) background paper, commissioned by IDRC for the Third Meeting of the SGUA, indicates that several current trends in urban agriculture are likely to expand and to transform the way it is done into the next century. Unemployment in Nigeria could be broadly divided into two main headings. Open unemployment and underemployment or disguised unemployment. According to Lambo (1987), open unemployment is mainly associated with the urban areas of the country, while disguised unemployment applies to the rural agricultural zone. Todaro (1992) described open unemployment to involve people who are able and often eager to work but for whom no suitable jobs are available, whereas underemployment or disguised unemployment is mainly for people who are normally working full time but whose productivity is so low that a reduction in hours would have a negligible impact on total output. The question now is what are the socio economic characteristics of youths in the study area? Also, what agricultural task do they perform?, what is their source of agricultural information?, what is their perception about urban agriculture? And what is the cause of unemployment among youths.

Objective Of The Study: The broad objective of this study is to assess the information needs of youths involved in urban agriculture as strategy for checking unemployment in Epe LGA of Lagos State, Nigeria. The specific objectives are to:

(i) examine the socio-economic characteristics of respondents in the study area.

(ii) ascertain the urban agriculture information needs of respondents

(iii) determine respondents' source of agricultural information.

(iv) identify reasons for unemployment among youths in the study area.

(v) identify respondents' perception of issues relating to urban agriculture

(vi) identify agricultural task of respondents.

Hypothesis Of The Study: There is no significant relationship between the socio-economic characteristics of youths and their perceived information needs about urban agriculture in solving unemployment in Epe Local Government Area of Lagos State.

Methodolog: The study was carried out in Epe LGA of Lagos State, Nigeria. The area is made up of nineteen (19) wards of which five (5) are urban where urban agriculture is practiced. A two stage sampling technique was used in selecting respondents for the study. The first stage was to select 3 wards out of the five wards purposively for the study because of intensive agriculture practiced. The three wards are Papa, Itaopo/Marina and Erepoto. The second stage was to select 50 young farmers from each of the three wards, making a total of 150 respondents. However, only 140 of the instrument were found useful.

Data used in accomplishing the objectives of this study were primary in nature and obtained through the use of questionnaire validated by experts in the field of agricultural extension. The reliability ( $\mathrm{r}=$ 0.82) of the instrument was achieved by test-retest method and Pearson Correlation.

The respondents were asked questions relating to socio economic characteristics, area of information needs in urban agriculture, and their sources of information. Respondents were asked seven questions relating to their perception of issues in urban agriculture, and their perceived causes of unemployment. Data were analyzed using frequency count, percentage and mean while hypothesis was tested using chi-square $\left(\mathrm{x}^{2}\right)$.

\section{RESULTS AND DISCUSSION}

Socio-Economic Characteristics of Respondents: Entries in table 1 reveal that most $(50.7 \%)$ of the respondents were males, $56.6 \%$ were married, most $(44.3 \%)$ had secondary education and $33.9 \%$ were between 21 - 30 years of age with a mean age of 28.7years. Most $(50.7 \%)$ had household size of between 4 and 6 persons and majority (71.4\%) was unemployed, while most $(37.2 \%)$ said they were farming on part-time basis. The implication of the findings is that the respondents are relatively young people who are ambitious, active and energetic to absorb the rigors in farming, responsibly married and educated, taking the base line of education to be primary school, the household size agrees with the findings of Edeoghon and Ajayi (2009) that modal household size of farmers in Edo state is $4-6$ persons. Unemployment amongst youths in the study area is high enough for them to accept urban agriculture as remedy either on full time or part-time basis. 
Table 1: Distribution of Respondents according to Socio Economic Characteristics $(\mathrm{n}=140)$

\begin{tabular}{|c|c|c|c|}
\hline Variables & & Frequency & Percentages $(\%)$ \\
\hline \multirow[t]{2}{*}{ Gender: } & Male & 71 & 50.7 \\
\hline & Female & 69 & 49.3 \\
\hline Age (Years): & $<20$ & 24 & 17.1 \\
\hline \multirow[t]{3}{*}{$\bar{X}=28.7$} & $21-30$ & 55 & 39.3 \\
\hline & $31-40$ & 46 & 32.9 \\
\hline & $41-50$ & 15 & 10.7 \\
\hline \multirow[t]{3}{*}{ Marital Status: } & Single & 49 & 35.0 \\
\hline & Married & 79 & 56.5 \\
\hline & Divorced & 15 & 8.5 \\
\hline \multirow{6}{*}{ Level of Education: $\mathrm{N}$} & No formal education & 2 & 1.4 \\
\hline & Primary School & 10 & 7.1 \\
\hline & JSSCE & 8 & 5.7 \\
\hline & SSCE & 62 & 44.3 \\
\hline & $\mathrm{OND} / \mathrm{NCE}$ & 41 & 29.3 \\
\hline & HND/Degree & 17 & 12.1 \\
\hline \multirow[t]{3}{*}{ Household Size: } & $<3$ & 45 & 32.1 \\
\hline & $3-6$ & 71 & 50.7 \\
\hline & $>6$ & 24 & 17.1 \\
\hline \multirow[t]{2}{*}{ Employment Status: } & Yes & 29 & 28.6 \\
\hline & No & 111 & 71.4 \\
\hline \multicolumn{2}{|c|}{ Part-Time Occupation: Trading } & 45 & 32.1 \\
\hline & Business & 15 & 10.7 \\
\hline & Farming & 52 & 37.2 \\
\hline & Artisans & 28 & 20.0 \\
\hline
\end{tabular}

Source: Field Survey

Information Needs of Respondents Involved in Urban Agriculture: Table 2 revealed information needs of the respondents. Most (28.6\%) of the respondents are of the view that the information needed to sustain their involvement in urban agriculture is in both in crops and animal production. $25.7 \%$ and $24.3 \%$ of the respondents needs information on crop production and fisheries respectively, while $5.7 \%$ of the respondents needs information on animal production and processing/marketing respectively. The implication of this result is that all the respondents needs information in at least one area of interest in agriculture. The quest for information in these areas of agriculture by the respondents can be attributed to the fact that the respondents are desirous to be skilled in these areas as a strategy to check unemployment, generate income and achieve food security through their involvement in urban agriculture. This result will collaborates the finding of Heckman et al (1987) that labour force surveys have shown that unemployment is significant higher in urban areas.

Table 2: Distribution of Respondents by Information Needs

\begin{tabular}{|c|c|c|}
\hline Areas involved & Frequency* & Percentage $(\%)$ \\
\hline Crop Production: crop spacing, fertilizer application, improved variety, seed multiplication, irrigation. & 76 & 54.3 \\
\hline $\begin{array}{l}\text { Animal Production: breeding stock, feed formulation, disease control, improved varieties, and routine } \\
\text { management practices. }\end{array}$ & 66 & 34.6 \\
\hline Processing/marketing: post harvest techniques, preservation, storage, packaging, price information. & 8 & 5.7 \\
\hline $\begin{array}{l}\text { Fisheries: feed formulation (plant and animal sources), breeding of fingerlings, disease control, pond } \\
\text { preparation, cropping/ harvesting }\end{array}$ & 34 & 24.3 \\
\hline
\end{tabular}

Source: Field Survey *Multiple responses

Respondents Source of Information about Urban Agriculture : Table 3 revealed that most (35.0\%) became aware and source information about urban agriculture through extension agents, while $25.0 \%$ source of information is friends/relatives. Also $15.7 \%$ of the respondents source information though both extension agents and friends/relatives. $20.7 \%$ and $3.6 \%$ source information through radio and newspapers respectively. It shows that all the respondents have keenly source information from different sources probably as available to them, it thus follows that they have high interest in urban agriculture. This could be as a result of lack of job. The result is similar to the findings of Edeoghon et al (2008) in their study of awareness and use of the sustainable agricultural practices by arable crop farmers in Edo state, Nigeria. The result also validates the study of Isiaka (1999), who 
recommended that agriculture as a subject should be introduced in both primary and secondary schools curriculum for everybody to be abreast of urban agriculture.

Table 3: Distribution of Respondents by Source of Information about Urban Agriculture

\begin{tabular}{|l|c|c|}
\hline Source & Frequency* & Percentage (\%) \\
\hline Extension Agents & 49 & 35 \\
Friends/Relatives & 35 & 25 \\
Radio & 29 & 20.7 \\
Newspaper & 5 & 3.6 \\
Extension Agents \& Friends/Relatives & 22 & 15.7 \\
\hline
\end{tabular}

Source: Field Survey

Respondents' Perception on Issues Relating to Urban Agriculture: Entries in Table 4 revealed that the most issue relating to urban agriculture by the respondents is "urban agriculture can supplement household food needs" ( $\mathrm{X}=4.44)$ followed by "Urban agriculture is practiced to supplement income" $(\mathrm{X}=4.37)$ and "Urban agriculture can be a solace to the unemployed" ( $\mathrm{X}=4.27)$. This perception accommodates the ascertion of Todaro (1992) that open unemployment involve people who are able and often eager to work but for whom no jobs are available. This also agrees with the findings of Lambo (1987) that open unemployment is mainly associated with urban areas in the country.

The implication of the result in Table 5 is that the youths see involvement in urban agriculture as a means of checking problems associated with youths rural - urban migration most especially food security and unemployment.

Table 4: Perception on Issues relating to urban agriculture

\begin{tabular}{|l|c|c|}
\hline Issues & & $\begin{array}{c}\text { Standard } \\
\text { Deviation }\end{array}$ \\
\hline Urban agriculture can supplement household food needs & Mean (X) & \\
Urban agriculture is practiced in supplementing income & 4.44 & 0.679 \\
Urban agriculture can be a solace to the unemployed. & 4.37 & 0.772 \\
Rare vegetable species can be grown. & 4.27 & 0.897 \\
Urban agriculture can easily be managed & 4.27 & 0.897 \\
All age groups can practice urban agriculture & 4.16 & 0.862 \\
Urban agriculture cannot be practiced on a large scale. & 3.85 & 1.061 \\
\hline
\end{tabular}

Source: Field Survey

Respondents' Agricultural Task: Respondents agricultural task reveal the agricultural task of respondents: Vegetable production $(\mathrm{X}=3.52)$, Maize $(\mathrm{X}=3.47)$ and Cassava $(\mathrm{X}=3.23)$ were the major crops grown by the respondents.

Results reveal that for livestock, fisheries/fish production was the most agricultural task practiced by respondents $(X=4.12)$ since the means of other aspects of livestock production (pig, rabbit, sheep, goats, snails, poultry) was less than 3.0. The high involvement of respondents in vegetable and fish farming can be attributed to the fact that the study area is riverside, as the aspect of production needs steady water availability

Table 5: Distribution of Respondents by Agricultural Task

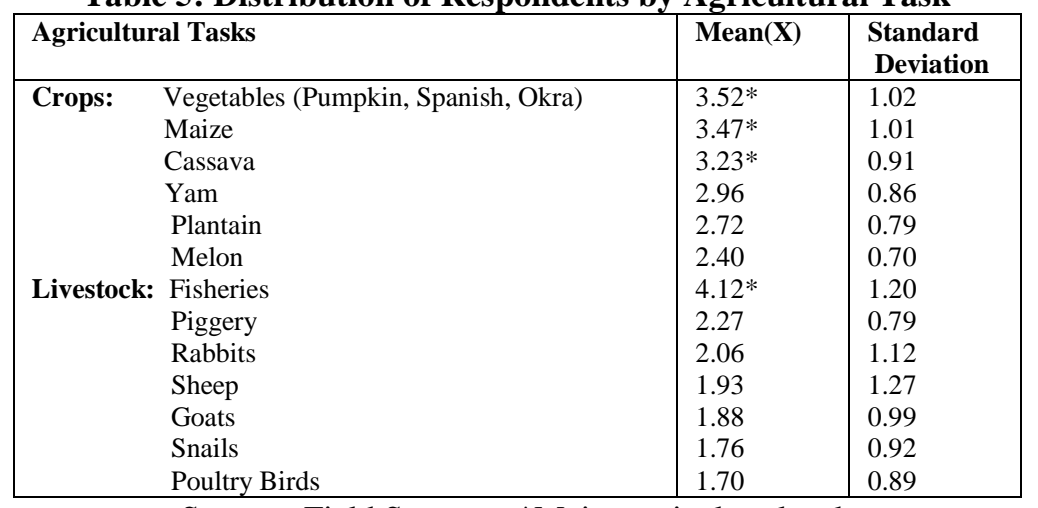

Source: Field Survey *Major agricultural task

Respondents' perception of causes of unemployment: Entries in Table 6 revealed that most $(28.6 \%)$ of the respondent feel that laziness on the part of the youths, is responsible for unemployment, while $21.4 \%$ and 
$20.7 \%$ say is lack of knowledge and lack of education respectively, yet $19.3 \%$ and $10.0 \%$ feel that godfatherism and government inability to provide jobs are causes of unemployment. The implication of this finding is that the youths feel that those who are not lazy should engage themselves in urban agriculture as a means of checking unemployment.
This result is similar to findings of Oni (1994) that high unemployment incidence of secondary school leavers are a reflection of improper coordination of educational system and policy prescription. Effect is that practical knowledge in agriculture is desirable by the youths.

Table 6: Distribution of Respondents by Perception of Causes of Unemployment

\begin{tabular}{|l|l|l|}
\hline Causes & Frequency* & $\begin{array}{c}\text { Percentage } \\
(\%)\end{array}$ \\
\hline Laziness & 40 & 28.6 \\
Lack of knowledge & 30 & 21.4 \\
Godfatherism & 27 & 19.3 \\
Lack of education & 29 & 20.7 \\
Government inability to provide jobs & 14 & 10.0 \\
\hline
\end{tabular}

Source: Field Survey

Hypothesis: Association between Respondents' Socio-Economic Characteristics and Their Perceived Information Needs about Urban Agriculture in Solving Unemployment: Results in Table 7 reveal that only level of education $\left(x^{2}=13.465: p<0.05\right)$ and primary occupation $\left(x^{2}=7.125: p<0.05\right)$ had significant relationship with respondents' perceived information needs about urban agriculture as a mean of employment. The result suggests that the more educated youths will have a higher perception need for information about urban agriculture. This result is in line with the assertion of Kiplang'at (2003) that education level is an important factor that influences agricultural information need and use. The association of primary occupation with urban agriculture information needs suggest that unemployed youths who have taken urban agriculture as their primary occupation will express a higher information need about urban agriculture.

Table 7: Association between Respondents' Socio-Economic Characteristics and Their Perceived Information Needs about Urban Agriculture in Solving Unemployment

\begin{tabular}{lcc}
\hline \multicolumn{1}{c}{ Variables } & $\mathrm{X}^{2}$ value & P-level \\
\hline Gender & 0.911 & 0.340 \\
Age & 3.465 & 0.325 \\
Marital Status & 3.213 & 0.523 \\
Level of Education & 13.465 & $0.035^{*}$ \\
Family Size & 1.801 & 0.615 \\
Employment rate & 0.322 & 0.851 \\
Enterprise & 1.691 & 0.792 \\
Primary Occupation & 7.125 & $0.042^{*}$ \\
\hline
\end{tabular}

* Significant at $5 \%$ level of significance

Conclusion And Recommendationse study revealed that the mean age of the respondents is 28.7 years; most $(54.3 \%)$ seek information in crop production. The major causes of unemployment among youths are laziness, lack of knowledge, government inability to provide job, godfatherism and lack of education. The major agricultural tasks of the respondents are vegetable, cassava, maize and fish production.

Recommendations: Based on findings, the following recommendations are made; he department of agriculture in Epe Local Government and Lagos state Agricultural Development Programme (ADP) should: provide youths with the needed information in agriculture especially in crops and fisheries where interest have been indicated the other areas of agricultural production i.e. yam, plantain, melon, piggery, rabbitary, sheep, goat, snailery and poultry production in which youth involvement in agriculture is low in Epe Local Government Area should be enhanced through provision of technical information by the agricultural extension agents who communicate these information needs to the youths as these agricultural products are in demand by the Nigerian populace information on processing and marketing of agricultural products should be provided for the youths in the area of preservation and market prices both at the local and international levels for the young people to have knowledge of higher profits and be inspired to take agriculture as a career and provision of technical and management assistance should be given to the youths for small agricultural enterprises.

The Ministry of Education in Lagos State should include agricultural skill training in both the primary school and secondary school curriculum to keep children abreast enough of new information for practicing agriculture hence checking idleness and unemployment through involvement in agriculture. he social and economic aspirations of the youths should be espoused and systematically inculcated into agricultural programmes. 
The three tiers of government should promote small scale enterprises linked with urban agriculture, i.e. input supplies (compost production, plant and fruit trees nurseries) and enterprises for marketing locally produced food.

Local Government Authority should support by mapping out lands that can be used temporarily and permanently for urban agriculture.

Implication for Millennium Development Goals: The very first of the millennium development goals addresses extreme poverty and hunger (Baba, 2009), a situation which can be caused by unemployment. Urban agriculture can go a long way in addressing this issue since it takes care of household food security, income and improved standard of living for those involved and it is also spontaneous. Youth involvement would also ensure the target of 2015 (i.e. halving those living in extreme poverty and hunger) being reached faster than with any other group because they are vibrant. Since over $70 \%$ of income of poor households goes into feeding (IDRC,1998) urban agriculture which is a poverty coping mechanism would therefore help a great deal in helping poor households in conserving money which can be used to better other areas of their lives.

Hence the unemployed youths need information to bridge between the known and unknown in the area of skills, competencies and training in urban agriculture. Information therefore is needed to give the empirical data about youth involvement in urban agriculture as a means of checking unemployment which this study provides as a means for attaining the millennium development goals.

\section{REFERENCES}

Baba, A. (2009). Millenium Development Goals, Social Transformation and the Civil Society in Nigeria. http://solidarityandstruggle.blogspot.com/2009/12/mill eniumdevelopmentgoals

Bennel, P. (2000). Improving Youth Livelihood in SSR Report to the International Development Centre. Business Dictionary, 2008. http://www.businessdictionary.com.

Chigunta, F. (2002). The Socio-economic Situation of youths in Africa: problems, prospects, Cities, Growing Food: Urban Agriculture on Policy Agenda, Fefdafing: DSE. Countries pp $29-39$

Edeoghon, C. O., Ajayi, M. T. and Ugboya, T. O. (2008). Awareness and Use of Sustainable Agricultural Practices by Arable Crop Farmers in Ikpoba-Okha Local Government Area of Edo state. Journal of Sustainable Development in Agriculture and Environment. Vol. 3, No. 2, pp $55-63$.

Edeoghon, C. O. and Ajayi, M. T. (2009). An assessment of Agricultural Enterprises owned by Women Farmers in
Ikpoba-Okha Local Government Area, Edo state, Nigeria. Global Journal of Agricultural Sciences. Vol. 8, No. 2, pp $153-158$.

Garnett, T. (1996). Farming the City: The Potential of Urban Agriculture. The Ecologist 26: 299 - 307

Heckman, J. and Joseph, V. H. (1987) An Investigation of the Labour Market Earnings of Panamaniah Males. Journal of Human Resources 21(1) 507.

IDRC (International Development Research Centre) (1998). Development research in urban agriculture, an international awards program. IDRC, Ottawa, ON, Canada Mimeo.

Igbinovia, P. (1998). Perceptive on Juvenile Delinquency in Africa. International Journal on Adolescence and Youth 1(2) $131-156$

Isiaka, B. T. (1996). An appraisal of the apprenticeship system in the training of out-of-school youths.

Jacobi, P. (1998). Food production as a survival strategy for urban household Paper presented on "urban food production, urban household, constraints and kinbased links between Rural and urban households" Nairobi, Kenya, 3 - 5 May.

Kiplang' at, J. (2003). 'Does Agricultural Extension have a new beginning because of ICTs? Reflection on Experiences in sub-Saharan'. Keynote Paper presented at the $6^{\text {th }}$ Consultative Expert Meeting on CTA's Observatory on ICTs. Wagenigem. September. 23 $25,2003$.

Lambo, T. (1987). Nigerian Economy. Textbook of Applied Economics. Lidato Press.

Moustier, P. (1998). La Complementarite entre agriculture urbaine et agriculture rurale. In: Olanrewaju B. Smith (ed). Agriculture urbaine en Afrique de I'Quest: UNe "assainissement des villes (Wageningen: CTA/ Ottawa: IDRC).

Onah, F. O. (2001) Urban Unemployment Situation in Nigeria. In: Ezeani, E. O. and Elekwa, N. N. (eds), Issues in Urbanization and Urban Administration in Nigeria. University of Nigeria, Nsukka. Jamo Enterprises, Enugu Nigeria. Pp. 154 - 167.

Rees, W. E. (1997). Ecological Footprints and the Imperative of Rural sustainability In: Ivone Audirac (ed). Rural sustainability in America, New York: John Wiley and sons.

Smit, J. (1996). Urban Agriculture, Progress and Prospective: 1997 - 2005. International Development Research Centre Ottawa, ON, Canada. Cities Feeding People Report 18.

Todaro, M. (1992). Economics for a Developing World, 2nd Ed. England. Longman Group, UK. Limited. 